\title{
Masculinidades en el discurso publicitario
}

\section{Masculinities in advertising discourse}

\author{
Ana Carolina Ferreiro Habra anacarolina.fh@hotmail.com \\ http://orcid.org/0000-0001-6003-1667 \\ Instituto de Estudios para el Desarrollo Social; \\ Facultad de Humanidades, Ciencias Sociales y de la Salud; \\ Universidad Nacional de Santiago del Estero/ Consejo Nacional \\ de Investigaciones Científicas y Técnicas (Argentina)
}

\section{Resumen}

El objetivo de este trabajo es examinar los modelos de masculinidad encontrados en las publicidades nacionales de productos dedicados al cuidado corporal/estético de los varones, de las marcas Nivea, Gillette, AXE, Rexona y Dove. Se consideran las publicidades puestas en circulación en las redes sociales (Facebook, Instagram y Twitter) de cada marca, desde enero de 2014 hasta diciembre de 2016. Se apunta a presentar un análisis semiótico global de las publicidades, ayudando a reconocerlas como una tecnología de género, dado que condensan un ideal social para varones y mujeres. Si bien hay diversidad de opciones para los varones, todas sostienen un modelo de masculinidad hegemónica, lo que se logra no sólo con publicidades que promueven los rasgos valorados de la misma, sino con otras que ridiculizan, niegan o critican formas alternativas de ser varón, vinculadas -generalmente- a la homosexualidad. También se proclama una complementariedad entre los sexos, como forma 
de defender una supuesta naturaleza diferenciada, mientras se ofrecen a los varones productos para reafirmar su masculinidad.

Palabras clave: Masculinidades; publicidades; estética.

\section{Abstract}

The purpose of this work is to examine the models of masculinity found in the national advertising of products from brands that target the corporal/aesthetic care of men (Nivea, Gillette, AXE, Rexona and Dove). It takes into consideration the advertisements placed on social networks (Facebook, Instagram, Twitter) of each brand, from January of 2014 up to December of 2016. It aims to present a global, semiotic analysis of the advertisements, in an effort to help people recognize them as a technology of gender, because they condense a social ideal for men and women. While there is a diversity of options for males among advertisements, all of them maintain the model of hegemonic masculinity, which is achieved not only with advertisements that promote the valued traits of it, but with others that ridicule, deny or criticize alternative ways of being male, generally linked to homosexuality. There are, also, hints of a complementarity between the sexes, defending a supposed differentiated nature, while men are offered products to reaffirm their masculinity.

Keywords: Masculinities; advertising; aesthetic.

Los estudios de género latinoamericanos han revelado que existen distintos modelos de ser varón, culturalmente aprendidos y construidos. Estos varían en una misma sociedad, según la época histórica (Margulis, 2003). De hecho, en un momento particular, coexisten masculinidades diversas, aunque un modelo suele tener mayor legitimidad que el resto. Si bien siempre se dan disputas acerca de cuál es la masculinidad hegemónica, se conserva el objetivo de garantizar la posición dominante sobre las mujeres (Connell, 1997; Connell y Messerschmidt, 2005). Bourdieu reconoció que los varones (al igual que las mujeres) son víctimas ocultas, ya que las tendencias que los conducen a reivindicar y ejercer el poder no son naturales, sino que se construyen a través de la socialización (2000).

El género no sólo codifica diferencias y divisiones entre mujeres y varones, sino también entre unas formas hegemónicas de masculinidad y otras minoritarias (Weeks, 2012). El 
reconocimiento de esta jerarquía de masculinidades es parte de la experiencia que los varones homosexuales tenían, en la década de 1970, acerca de los prejuicios y la violencia de los varones heterosexuales (Connell y Messerschmidt, 2005). Segato (2006) explica que la masculinidad es un estatus que debe lograrse y reconfirmarse regularmente, a través de un proceso que implica pruebas o conquistas ante (o para ser relatada a) otros varones. Cualquier actitud, práctica, característica, gestualidad o corporalidad que se asocie a lo femenino es inquietante, amenaza a los varones en su identidad masculina, por lo que es ridiculizada y rechazada (Belmonte y Guillamón, 2008).

La familia es la fuente primaria de socialización, educación y reproducción de las matrices de género y simbólicas propias de una cultura, junto a otras instituciones como la escuela, los clubes, las iglesias. También los medios de comunicación condensan la oferta de un ideal social deseable, que funciona como un mecanismo por el cual los sectores hegemónicos fijan sus categorías culturales e imponen una forma de cotidianeidad (Urbano y Yuni, 2011). A través de su presencia cotidiana y sistemática, los medios de comunicación influyen en la configuración de las identidades sociales: son tecnologías sociales (Belmonte, 2014; Belmonte y Guillamón, 2008). De Lauretis (1996) introdujo la categoría de "tecnologías del género" en 1989, reformulando los aportes de Foucault (1) para visibilizar a las mujeres. La autora señaló que el cine constituye un aparato social para la construcción de subjetividades. Analizar la forma en que se representa a varones y mujeres permite develar la ideología implícita en esas producciones. Esto es extrapolable a las producciones publicitarias.

Según Caro (2017) la publicidad tiene, actualmente, una función ideológica-institucional, reemplazando a otras instituciones que perdieron su eficacia cohesionadora (como la política y la religión). Como composición deliberada, la publicidad presenta de forma reducida, estilizada y recurrente los modelos de pensamiento y las prácticas dominantes en una sociedad; entre ellos, las formas hegemónicas de ser varón y de ser mujer, en un momento dado y como una forma de legitimar la diferencia y la complementariedad sexual (Belmonte y Guillamón, 2008). Esto incluye lo esperado y estimulado, como así también lo condenado y censurable respecto a las conductas, a las formas de vinculación, presentación y expresión personal de varones y mujeres. Quienes se salen de las normas asignadas socialmente por este aparato regulador de heterosexualidad (Butler, 2002) deben enfrentar sanciones, que llegan a través de distintos mecanismos de control social (Hernández García, 2006).

La televisión, la radio y los medios gráficos eran -en décadas pasadas- los medios prioritarios a la hora de publicitar productos, pero internet proporciona un modo de acceso todavía más inmediato y permanente a la cotidianidad de los consumidores y consumidoras, dando lugar a 
la publicidad ubicua, es decir, que está en todo lugar, al mismo tiempo, es personalizada, contextualizada e interactiva.

Para Caro (2017), el mercado se encuentra en una fase semiocapitalista, caracterizada por la producción semiótica. Las publicidades han dejado de centrarse en los productos, para tomar por objeto a las marcas, que -en sí mismas- son signos huecos. Valiéndose de la generación de expectativas y de la forma en que es percibida la marca, se sustituye el valor de uso del producto por el valor de consumo.

También Berger (2002) advierte que las publicidades no se centran en los productos, sino en ofrecer una imagen de quién se podría llegar a ser. Para ello, inducen a sentir insatisfacción respecto al modo de vida presente, prometiendo transformar en objeto de envidia ajena a quien consuma sus productos. La publicidad genera fascinación respecto de un modo de vida, ofreciendo la posibilidad de distinguirse, lo que se asocia a un marcado individualismo (Caro, 2017). Como sostiene Berger: “(...) la veracidad de la publicidad no se juzga por el cumplimiento real de sus promesas sino por la correspondencia entre sus fantasías y las del espectador-comprador" (2002: 81). Sin embargo, esos ideales propuestos son inalcanzables, pues son construcciones publicitarias (Caro, 2017).

En este trabajo se busca identificar los modelos de masculinidad que muestran las publicidades de productos para el cuidado corporal y la estética de los varones, intentando describir el perfil de varón al que cada marca apunta desde sus publicidades y los aspectos de la masculinidad que estas defienden, critican o proponen, haciendo un análisis crítico de las imágenes, discursos y formatos que se ofrecen a los varones.

\section{Varones publicitarios}

Weeks (2012) afirma que, desde la Modernidad tardía, el cuerpo se constituyó como un tema ineludible en el proyecto reflexivo de cada persona. Hoy en día, la autoconciencia del cuerpo es central en cómo un sujeto se ve a sí mismo y en cómo se define, cómo actúa, se presenta ante los demás, quién es como persona. Porras y Molina observaron que, en las publicidades, los papeles preponderantes para los varones los muestran seguros, musculosos, fuertes, prestigiosos, adinerados y exitosos, presionando para la construcción de masculinidades hegemónicas (2011: 80). A entender de Cuadrado Zurinaga (2008), al igual que a las mujeres, a los varones se les está demandando un ideal de belleza que está por fuera de lo real. Lomas 
puntualiza: "La gran obsesión del cuerpo masculino y el gran fantasma con el que debe luchar el hombre publicitario es la ausencia de energía física y de vigor viril" (2003: 173-174).

Según Lomas, desde la segunda mitad del siglo XX, los varones publicitarios muestran su virilidad a través de un interés desmedido por el fútbol (y otros deportes), los automóviles y las mujeres y mediante un desinterés por lo doméstico que escape a la provisión de su salario (2003). Bonino Méndez (1998) se refiere al uso expansivo-abusivo del tiempo, como también del espacio, que hacen los varones. La disponibilidad de tiempo por fuera del trabajo pareciera ser ilimitada y dedicada al placer, lo que está contrapuesto, muchas veces, a la familia (pero no a los amigos).

Segato (2010) recomienda tener una escucha adecuada y advertida ya que, si bien superficialmente las interacciones sociales y la distribución de los derechos y deberes pueden parecer equivalentes, el soporte ideológico en que se apoya la jerarquía de prestigio de las tareas es patriarcal.

Al igual que Segato, Lomas advierte que:

Quizás se haya producido de forma irreversible (...) la crisis de la imagen estereotipada del macho agresivo y engreído en su supuesta superioridad frente a la mujer, pero no es fácil la identificación en las escenas publicitarias de la emergencia de otras maneras de ser hombres en las que la ternura, la sensibilidad y la expresión de los afectos y de los sentimientos constituyan un elemento esencial en la configuración de su identidad masculina (2003: 172).

Los varones que se interesan por cosas consideradas como femeninas (como el cuidado de la piel y el peinado y/o corte de cabello), sin ser homosexuales, son sujetos sociales pero son, también, una construcción publicitaria, conocida como "metrosexual" (2). Según Rey (2006), el término es conjunción de "metro" (vive en una metrópolis) y "sexual" (vive sin complejos su parte femenina) y designa a los jóvenes varones que se preocupan excesivamente por su cuerpo y por su indumentaria. Para Cuadrado Zurinaga (2008), esto no es un avance: el metrosexual interesa sólo a los fines de aumentar el consumo. Lomas (2003) considera que la imposición de rasgos de carácter, preceptos y normas de conducta específicos genera frustraciones, temores y dolor, ya que solo un pequeño porcentaje de varones se adecua completamente al modelo hegemónico de masculinidad (a costa de sacrificios y renuncias). 


\section{Metodología}

Para el corpus de análisis, se seleccionaron publicidades nacionales de antitranspirantes/desodorantes corporales, productos para el cabello, cremas faciales, jabones y geles de ducha, maquinitas de afeitar y productos asociados (espuma/gel de afeitar, bálsamo/after shave) de las marcas Nivea (Men), Gillette, Axe, Rexona (Men) y Dove (Men+Care) (3). Se consideraron las publicidades difundidas en las redes sociales (Facebook, Instagram, Twitter) de las marcas mencionadas, en 2014, 2015 y 2016.

Se apunta a presentar un análisis semiótico global de las publicidades representativas de los distintos modelos de masculinidad ofrecidos, desentrañando las ideas que les dieron lugar y los recursos usados para darles cuerpo (Caro, 2017). Ello implica desandar el operativo semiolingüístico que realizan las agencias de publicidad, entendiendo que sus productos son, a la vez, semióticos (producen significaciones imaginarias y construyen marcas) y lingüísticos (en tanto se sirven de palabras, recursos gráficos, imágenes, expresiones sonoras $\mathrm{u}$ otras formas concretas y comunicables) para producir determinados procesos de significación.

\section{Resultados}

Las marcas consideradas para este trabajo han incursionado en las redes sociales. Todas poseen, al menos, una cuenta de Facebook Argentina. En ellas, publican mensajes e imágenes que asignan determinados intereses y exigencias según una explícita división binaria de género. Esos mensajes son presentados como fieles representantes de una supuesta esencia masculina, como el desinterés por ir a los centros comerciales (shoppings), ya que el gusto por la ropa (que incluye ir a distintos negocios a elegirla, probársela, decidir) es atribuido culturalmente a las mujeres (Figura 1). La publicidad de Dove recupera el estereotipo del varón que va de compras para satisfacer a su pareja (mujer), contra su verdadero deseo (el gráfico de torta implica que la propuesta nunca surgiría de él). 


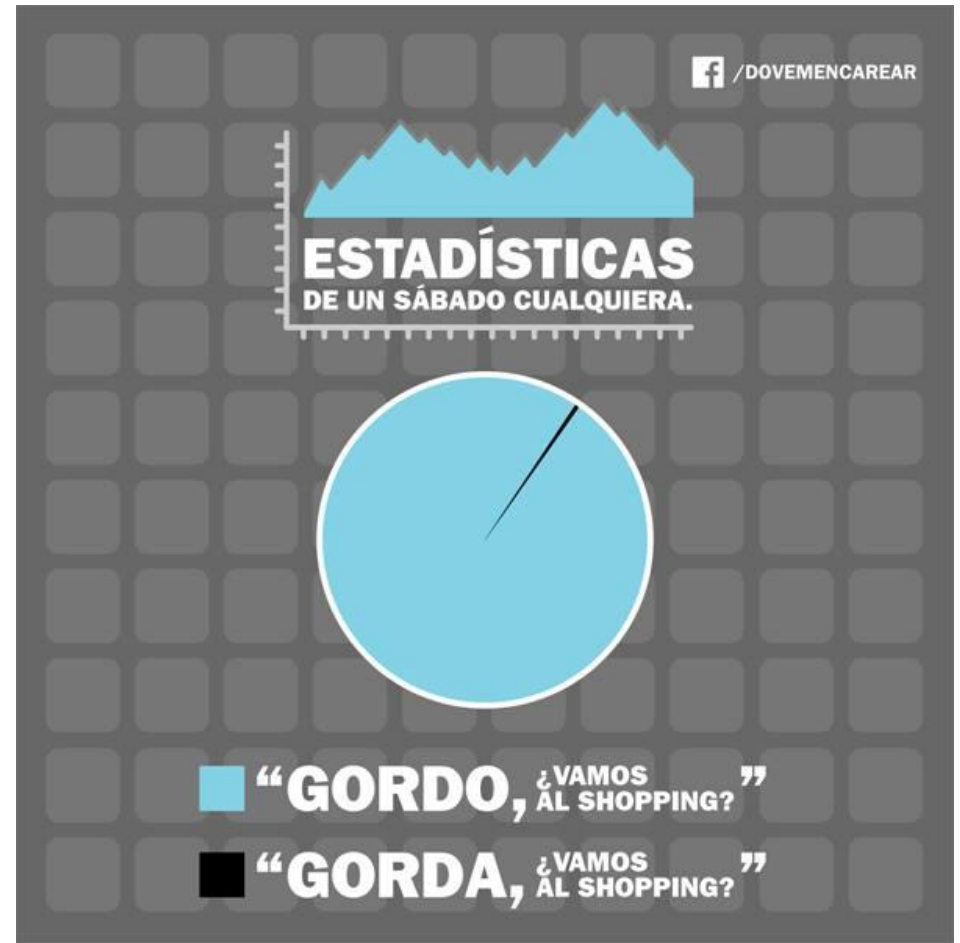

Figura 1: Dove Men+Care (@dovemencarear) (11 de enero de 2014). Epígrafe: “Una estadística irrefutable” (Actualización Facebook). Recuperado de https://bit.ly/2JcFSXm

Las publicidades analizadas muestran el estereotipo de varón urbano, de clase media o alta, heterosexual, mayoritariamente blanco y en diversas situaciones de la vida cotidiana (exceptuando a las de AXE, que suelen escenificar supuestas fantasías masculinas): a veces solo (por ejemplo, en el baño de su casa o en su habitación) y otras, en sus relaciones familiares (principalmente con sus hijos y/o hijas), sociales (amigos), laborales o realizando actividades deportivas.

La posibilidad de interactuar con los usuarios y usuarias de Facebook y/o Twitter, permite a las empresas responder a los comentarios que reciben usando recursos humorísticos y reforzando los mensajes transmitidos en sus publicidades. Como contraparte, Caro habla de una cultura publicitaria, ya que los receptores y receptoras rompieron con el lugar de pasividad que les fue dado históricamente, comenzando a interactuar activamente, a través de distintas plataformas tecnológicas (2017). Para este autor las publicidades están centradas en lograr insuflarle un alma a los productos. Por ejemplo, desde la cuenta de Facebook de Rexona, se respondió a un comentario que un usuario hizo a una imagen publicada: "Luis! No te abandono nunca y menos 
cuando estás en movimiento porque ahora tengo Rexona con MotionSense!" (4). Se observa que se responde personificando a la marca, no como una corporación.

La presentación de personajes reconocidos (actores, conductores, deportistas) como recurso publicitario, facilita la identificación de los espectadores con la marca. Lionel Messi (Figura 2) promociona los productos Gillette, funcionando como argumento de autoridad en materia de masculinidad, ya que encarna el modelo de varón heterosexual, exitoso en su vida personal está casado y tiene hijos- y profesional -futbolista consagrado-, con actitud relajada. Messi es constantemente puesto a prueba (o se pone a prueba) en el fútbol-deporte representativo de la masculinidad hegemónica-, y las publicidades de Gillette afirman que él no falla a la hora de demostrar su grandeza.

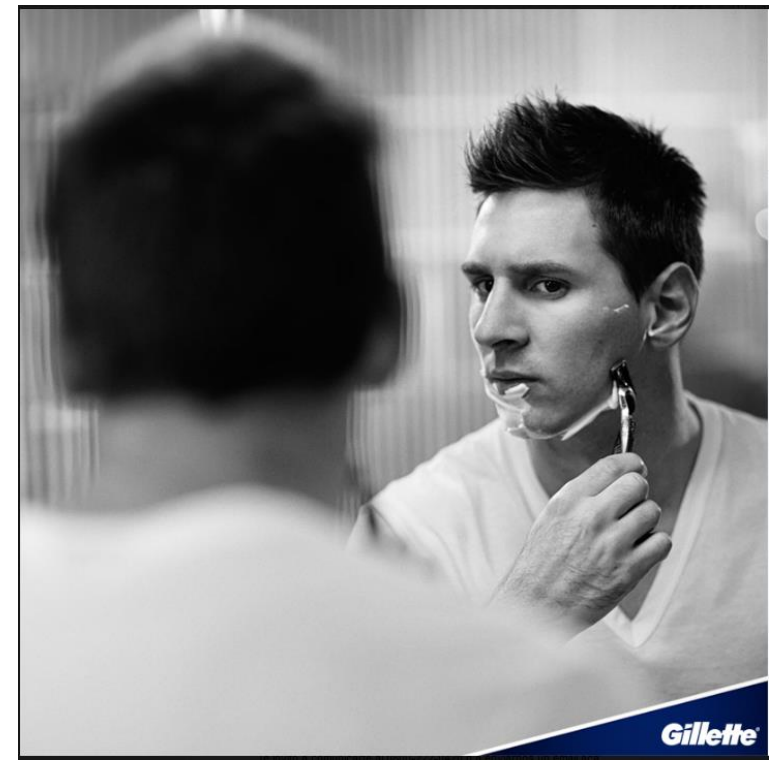

Figura 2: Gillette Argentina (24 de junio de 2015). Epígrafe: "Decir que eres grande es fácil, demostrarlo te hace enorme. ¡Feliz cumpleaños Messi!” (Actualización Facebook). Recuperado de https://bit.ly/2Gsz2LC

Bajo los lemas "Hacé: Más" y "Hacé más de lo que te gusta, porque Rexona no te abandona", la campaña de Rexona apunta a personas deportistas, activas, en diversas situaciones de trabajo y ocio. En 2014, durante la Copa Mundial de Fútbol, se recurrió al futbolista Javier Mascherano -conocido motivador de la Selección argentina-, combinando el eslogan de la marca con el apellido del jugador y diciendo "Hacé:Masche" (Figura 3). La publicidad de Rexona -como la de Gillette- condensa en un futbolista el ideal de masculinidad, destacándola como activa y sosteniendo el imaginario de vigor físico, competitividad y superación. 


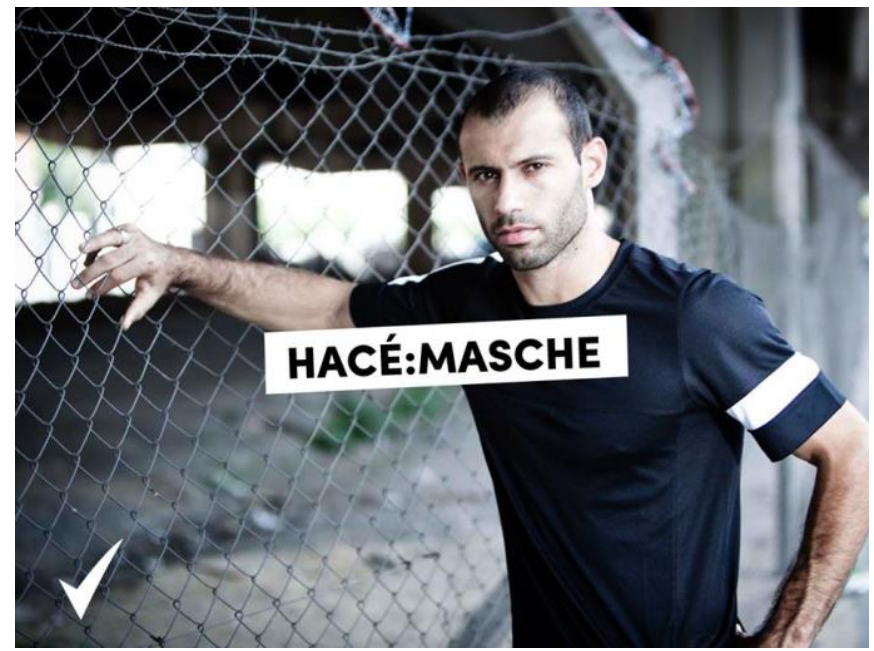

Figura 3: Rexona (Rexona Argentina) (10 de julio de 2014). Epígrafe: "Si buscás la definición de HACÉ:MÁS en el diccionario aparece la foto de Javier Mascherano. Vamos Argentina!" (Actualización Facebook). Recuperado de https://bit.ly/2q1VIRh

Nivea parece apuntar a un hombre cosmopolita y deportista. Sus publicidades hacen hincapié en la pasión por el fútbol, los videojuegos, y en ellas se habla de ser ganadores (Figura 4). Se valora la resistencia, la fuerza, el "aguante".

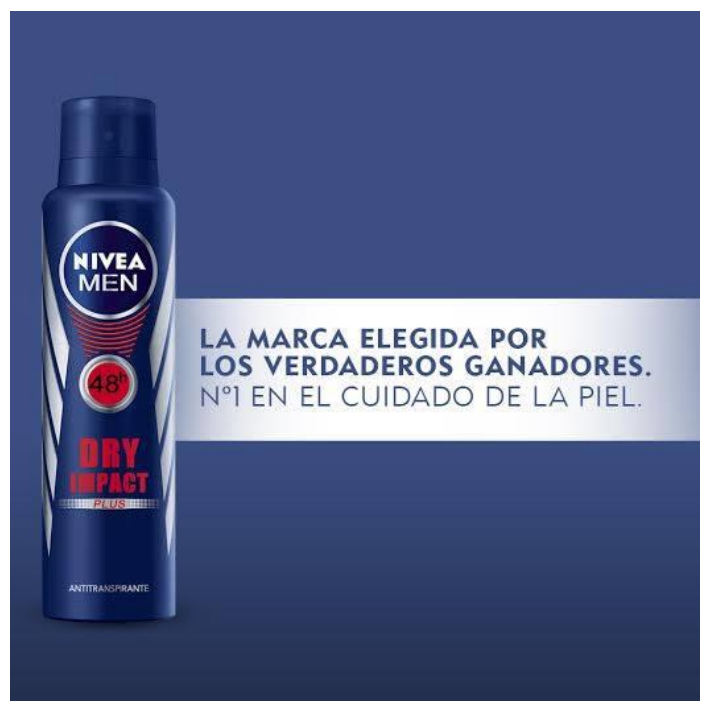

Figura 4: Nivea Men (@NiveaMenArgentina) (22 de septiembre de 2014). Epígrafe: NIVEA MEN DRY IMPACT no admite comparaciones (Actualización Facebook). Recuperado de https://bit.ly/2H6xSqa 
En las publicidades abundan los guiños humorísticos, intentando así tapar la imposición de normas de conducta y la estigmatización de lo diferente. Los vínculos entre varones, para Nivea Men, implican burlas y escraches públicos que ponen en evidencia a alguno de ellos como no suficientemente hombre. En ocasión del festejo de San Valentín (celebración comercial del amor romántico), la publicidad de esta marca previene a los varones para no ser/parecer demasiados sensibles (Figura 5), reforzando el estereotipo de que las emociones son privativas de las mujeres. Se sostiene también la idea de que ese lado femenino acecha peligrosamente, pudiendo aflorar en los varones que no tienen ciertas precauciones. Por eso, se hacen sugerencias a los varones, para que los regalos que hagan a su pareja (presumida mujer) sean regalos masculinos, como un osito de peluche que tenga puesta una camiseta del equipo de fútbol favorito del varón.

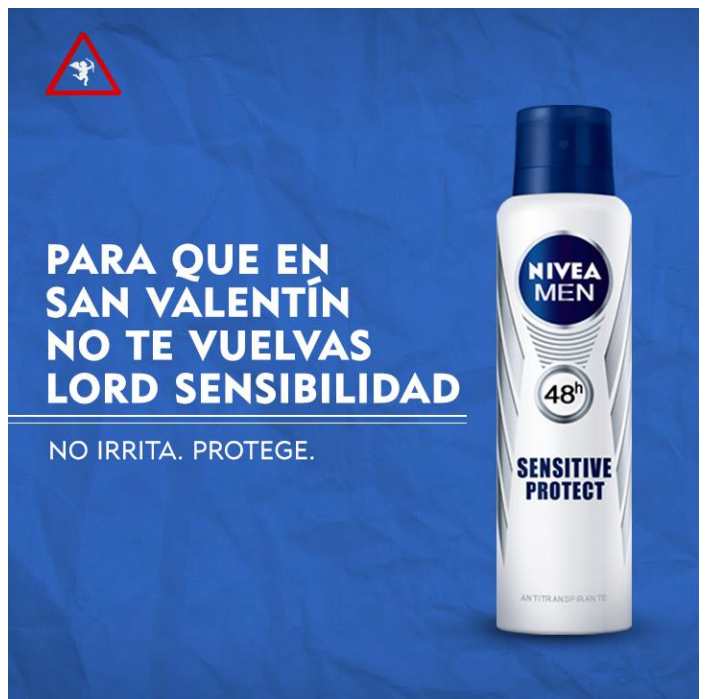

Figura 5: Nivea Men (@NiveaMenArgentina) (14 de febrero de 2014). (Actualización Facebook). Recuperado de https://bit.ly/2loJ7d7

La marca publicita otro desodorante, afirmando: "NIVEA Men presenta Invisible Black\&White. Te protege de las manchas, incluso de las que te quedaron de las vacaciones". La foto que acompaña la frase muestra la parte trasera de un varón (seccionado) con un traje de baño color rosa y el texto sobreimpreso: "El tema del verano fue tu short rosa" (Figura 6). Se apela, así, a estigmatizar a los varones que no responden a los patrones estéticos generizantes (la ropa de color celeste para los varones y la de color rosa para las mujeres). Se está respetando (y promocionando) un modelo binario y dicotómico (varón/mujer y varón/homosexual). Ante 
este aparato regulador de heterosexualidad (Butler, 2002), los varones reciben la indicación de ejercer una vigilancia permanente de su propia masculinidad y de las de sus pares, para evitar ser señalados en falta.

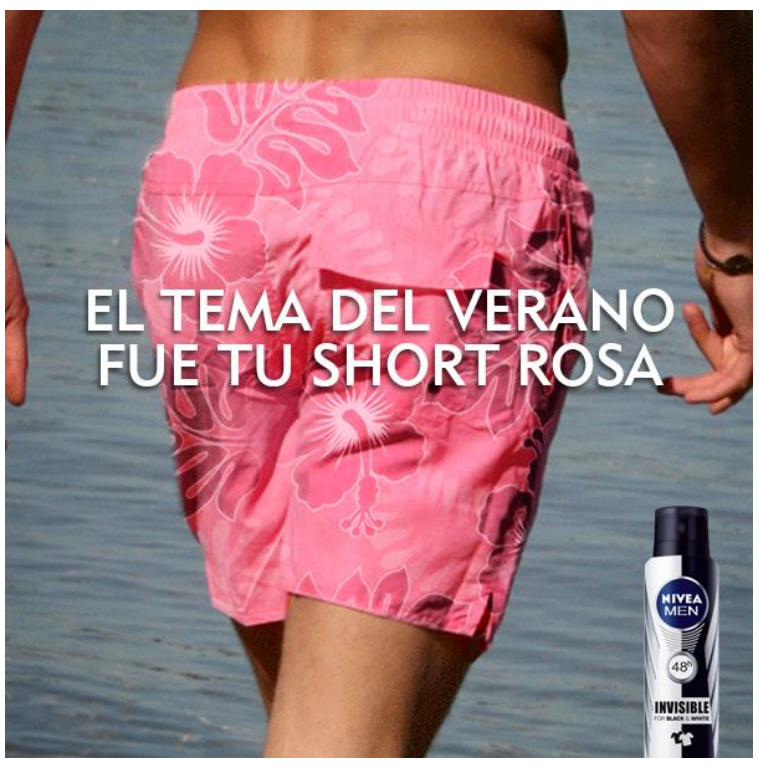

Figura 6: Nivea Men (@NiveaMenArgentina). (22 de septiembre de 2014). Epígrafe: “NIVEA Men presenta Invisible Black\&White. Te protege de las manchas, incluso de las que te quedaron de las vacaciones" (Actualización Facebook)

Recuperado de https://bit.ly/2GtflC1

Berger (2002) observó que en las publicidades se muestra la sofisticación de sus protagonistas mediante una desafectación que los hace imperturbables ante los conflictos. Esto parece guiar la campaña de AXE "Los impecables", que cuenta con distintas situaciones que los varones podrían enfrentar y que los harían transpirar o "perder su estilo", pero evitan esto usando el desodorante de la marca. Los mensajes publicados recurren a hipérboles, pues sus protagonistas se muestran impávidos ante experiencias típicamente estresantes, por ejemplo, cuando la grúa se lleva su auto o se quedan fuera de la casa con las llaves adentro de la misma (Figuras 7 y 8 ). 


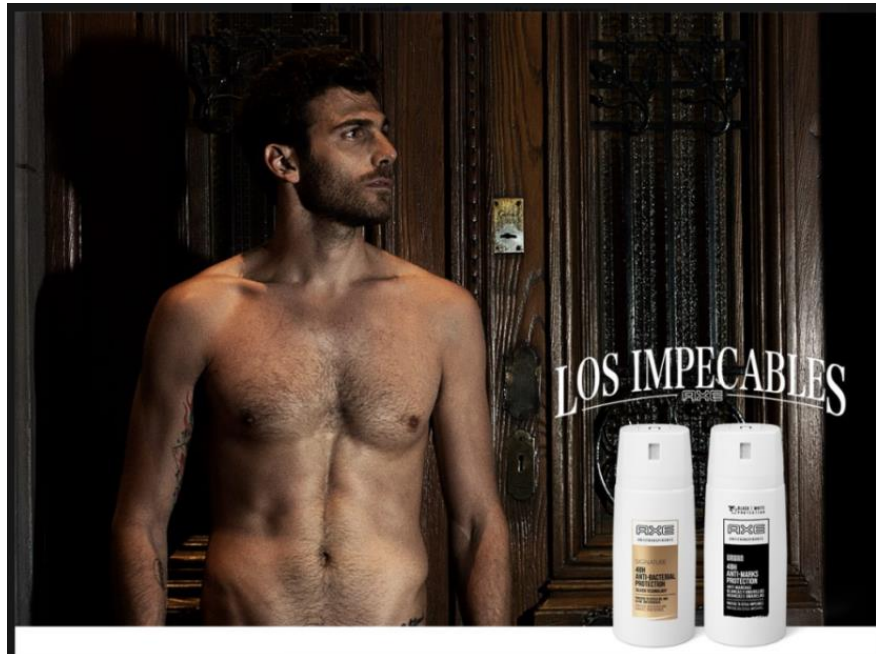

Figura 7: Axe Argentina. Epígrafe: "Parece que está reflexionando, pero en realidad se olvidó las llaves adentro. Él es uno de \#LosImpecables. Transpirar nunca. Perder tu estilo, jamás". (Actualización Facebook). Recuperado de https://bit.ly/2GQXARG

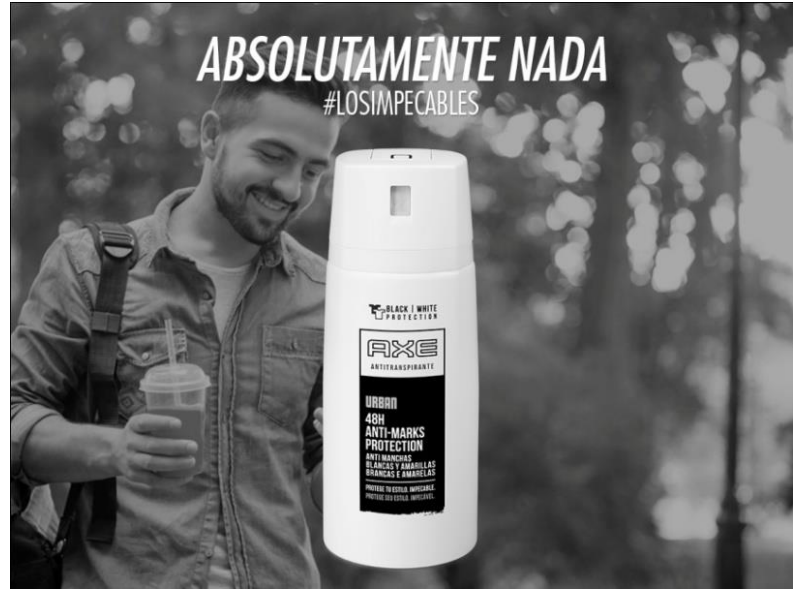

Figura 8: Axe Argentina (18 de noviembre de 2015). Epígrafe: “¿Qué pasa si la grúa te llevó el auto? Nada. Absolutamente nada. \#LosImpecables" (Actualización Facebook). Recuperado de https://www. https://bit.ly/2H5VAmj

Las campañas de Gillette y AXE destacan el estilo, brindando tips para encontrarlo y mantenerlo. Entre las marcas consideradas, AXE es la que apunta al público más joven: varones solteros, con "actitud", seductores, que buscan placer y diversión (generalmente vinculadas a la noche). Lucen ropa moderna, tienen una estética pulcra con detalles que llaman la atención (las estampas de la ropa, anteojos de diseño, un anillo importante o el modo en que llevan la barba). Gillette, por su parte, apunta a los deportistas -también solteros y seductores-, utilizando hipérboles en expresiones como "darlo todo" y "sin límites", reforzando la idea de que 
los varones deben rendir al máximo, poner/se a prueba (Figura 9). Esta estimulación del rendimiento -el vigor viril, ligado a la potencia sexual masculina- circula recurrentemente en la campaña publicitaria de la marca. Se presentan varones con el torso desnudo, como una forma de transmitir fuerza (la musculatura implica una dedicación de tiempo significativa al ejercicio físico) y de despertar la admiración de los espectadores.

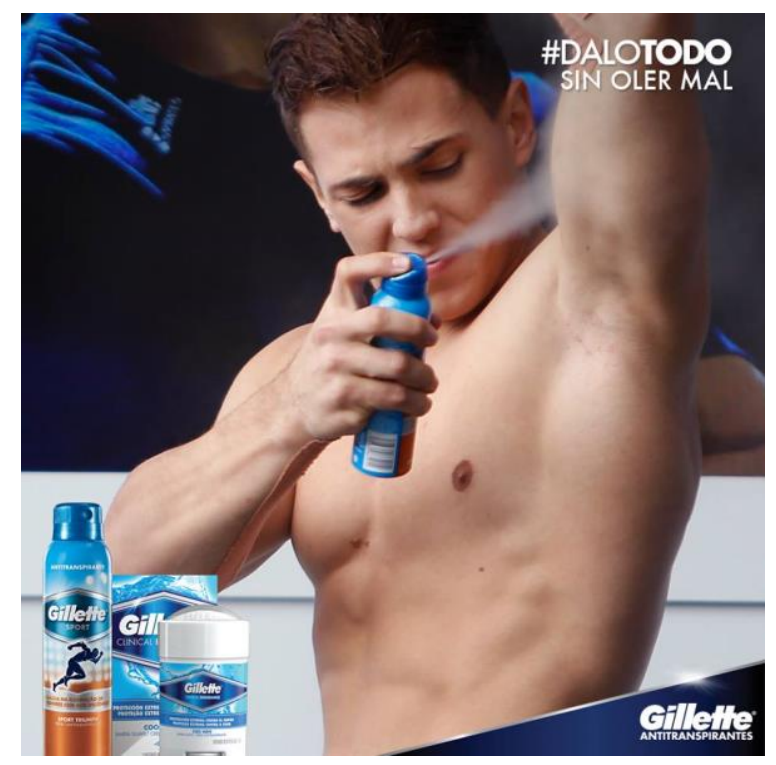

Figura 9: Gillette Argentina. (4 de octubre de 2014). Epígrafe: "Y vos, ¿ya pusiste la protección de \#GilletteAntitranspirantes a prueba? \#DaloTodo sin oler mal” (Actualización Facebook). Recuperado de https://bit.ly/2q0FD8Q

Las publicidades de Gillette mantienen la atención -típicamente masculina- en el poder y la jerarquía, mientras promocionan una maquinita de afeitar para el cuerpo, haciendo un paralelismo entre el "Rey de la selva" con el "Rey de la City (ciudad)" (Figura 10). Se recurre a la elipsis, ya que no se muestra a los varones, sino a su vello corporal, en oposición (antítesis), pues el primero tiene vello en el pecho y abdomen, mientras que el segundo se rasura ese vello. Como la depilación del vello corporal se asocia tradicionalmente a lo femenino y lo homosexual, los mensajes intentan asociar esta acción con características típicamente masculinas, diciendo: "Su habitat: tu ducha. Su presa: cada vello en tu cuerpo. Gillette BODY, la afeitadora perfecta para cazar cada vello del hombre" (Figura 11). El uso de términos metafóricos: hábitat (la ducha), terreno (el cuerpo), caza (la depilación), presa (los vellos), indica que se está evitando una imagen de debilidad y delicadeza. 


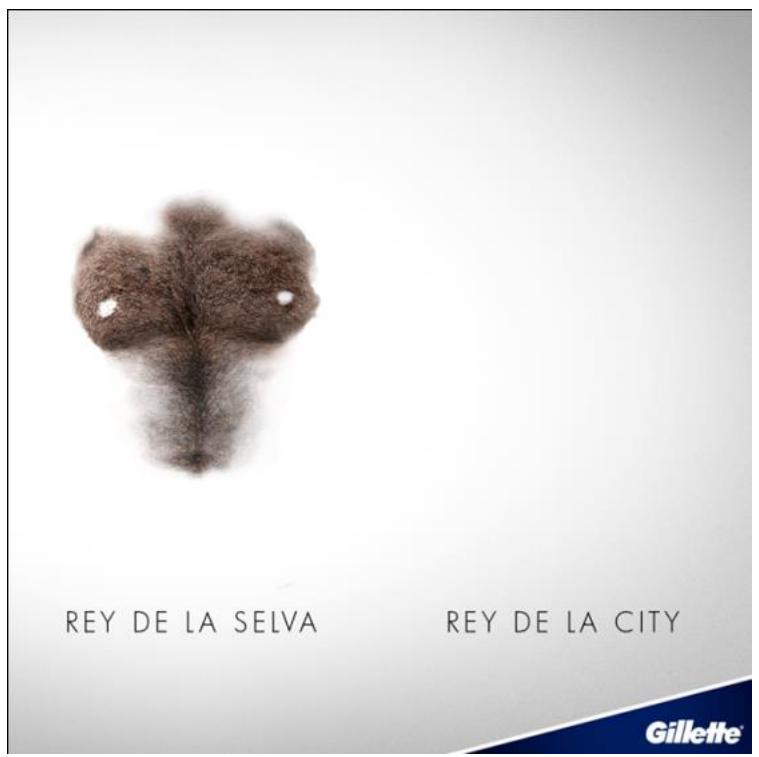

Figura 10: Gillette Argentina. (20 de noviembre de 2014). Epígrafe: "Una pequeña afeitada hace una gran diferencia". (Actualización Facebook). Recuperado de https://bit.ly/2pZSKrH

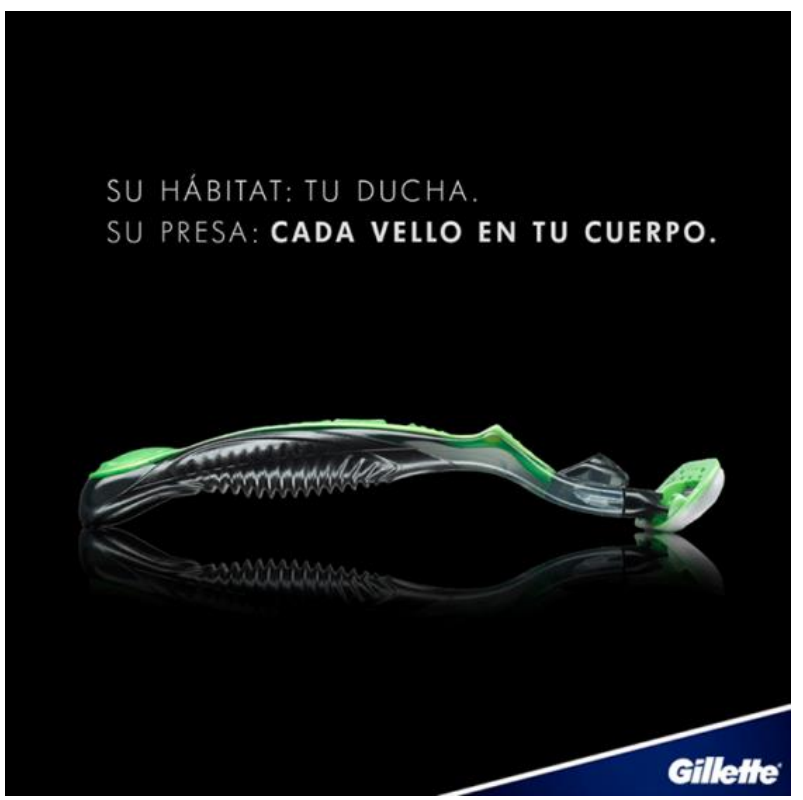

Figura 11: Gillette Argentina (30 de marzo de 2015). Epígrafe: Gillette BODY, la afeitadora perfecta para cazar cada vello del hombre. Conocela acá: http://goo.gl/38pqi6. (Actualización Facebook). Recuperado de https://bit.ly/2GNliNQ

La campaña de Dove Men+Care se centró en indicar qué hace que un varón sea fuerte, con situaciones que implican más fuerza de voluntad que fuerza física. Por ejemplo, jugar al fútbol a las once de la noche, como favor a un amigo -fortaleciendo la amistad con un par de género- 
(Figura 12) y trabajar horas extra para reafirmarse socialmente (Figura 13). A diferencia del resto de las marcas consideradas, se reconoce que las publicidades de Dove se dirigen a varones que se encuentran en una relación de pareja estable, con hijos y/o hijas. Esto contribuye a validar conductas y modos de vincularse que antes les estaban vedados.

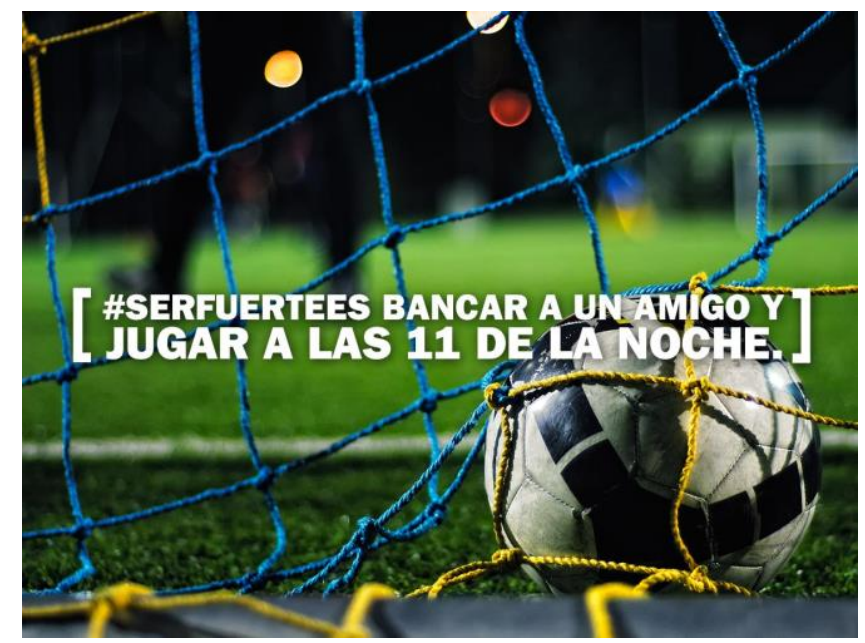

Figura 12: Dove Men+Care (@dovemencarear) (26 de julio de 2015). Epígrafe: El cuidado hace al hombre + fuerte. (Actualización Facebook). Recuperado de: https://bit.ly/2JeygU2

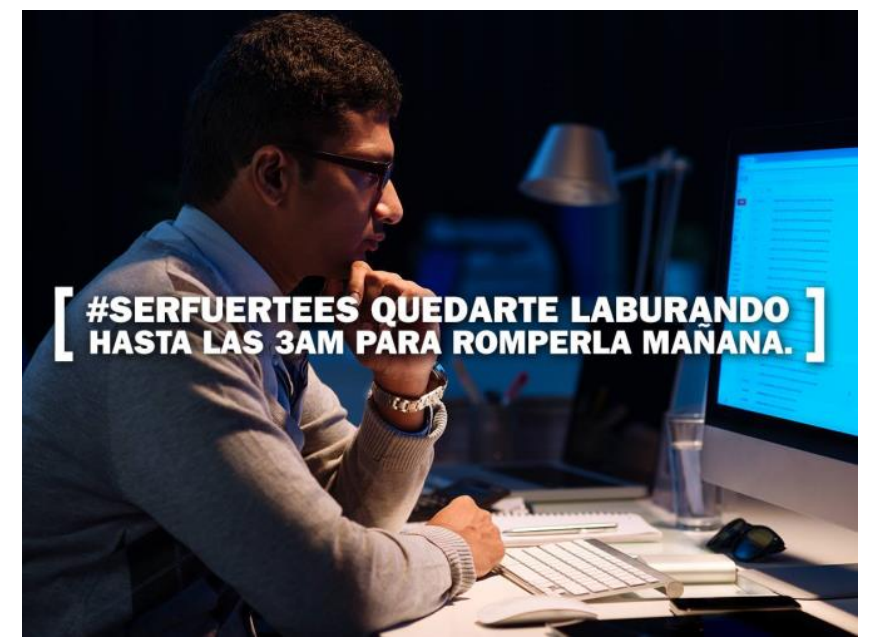

Figura 13: Dove Men+Care (@dovemencarear) (23 de agosto de 2015). Epígrafe: Cuidás los detalles en todo lo que haces. El cuidado hace al hombre + fuerte. (Actualización Facebook). Recuperado de https:// https://bit.ly/2uHk5UA

Poniendo el foco inicialmente en la fuerza/potencia, la campaña de Dove incorporó al cuidado, polarizada pero complementariamente, concluyendo que este hace más fuerte a los varones 
(Figuras 14 y 15). Los varones son resaltados en su rol paterno, no sólo jugando con sus hijos e hijas, sino enseñándoles (por ejemplo, a atarse los cordones, a hacer el nudo de la corbata o a hacer un asado), proveyendo primeros auxilios ante una herida, dándoles de comer y despertándose a cambiar pañales de noche (Figuras 16, 17 y 18). Se observa, en todo esto, un cambio respecto a la sensibilidad y a la expresión de los afectos de los varones publicitarios, al menos en lo que respecta a la crianza de sus hijos e hijas.

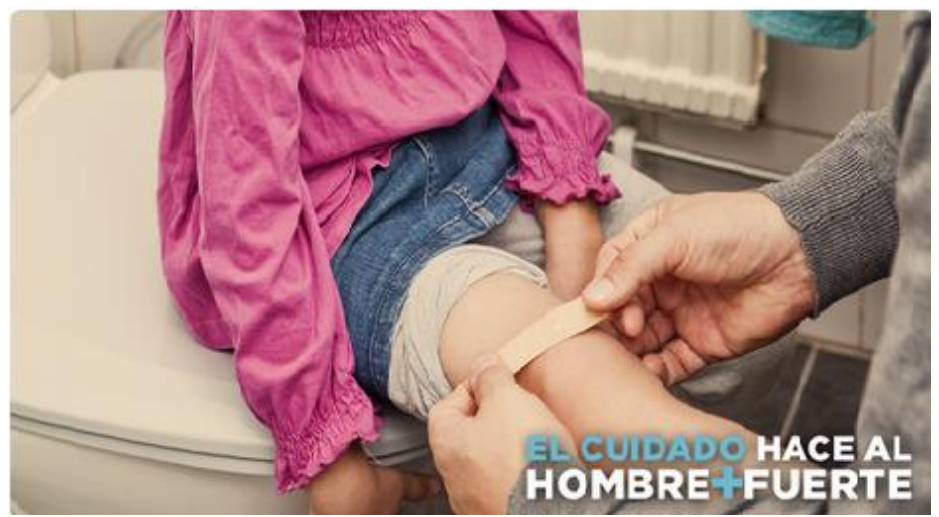

Figura 16: Dove Men+Care Arg (12 de octubre de 2015). Epígrafe: "Ellos saben quién es el primero al que tienen que llamar, si les pasa algo" (tuit). Recuperado de https://twitter.com/DoveMenAR/media?lang=es

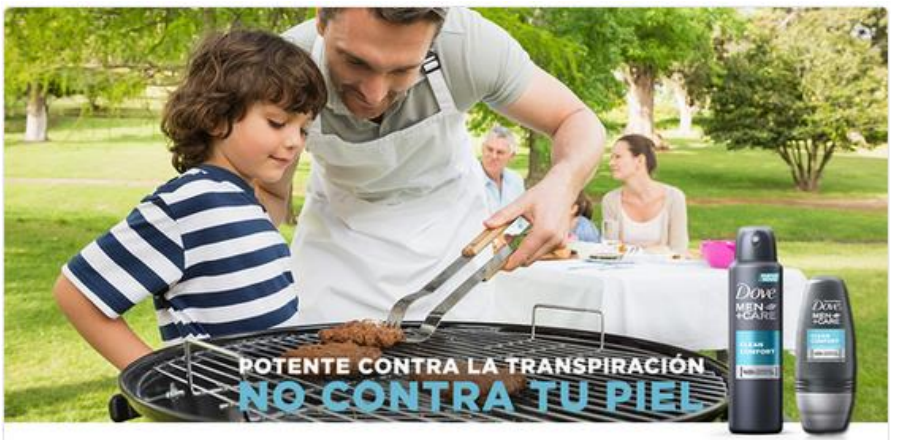

Figura 17: Dove Men+Care Arg. (15 de octubre de 2015). Epígrafe: "Enseñarles a hacer un asado, por más que te estés asando" (tuit). Recuperado de https://twitter.com/DoveMenAR/media?lang=es 


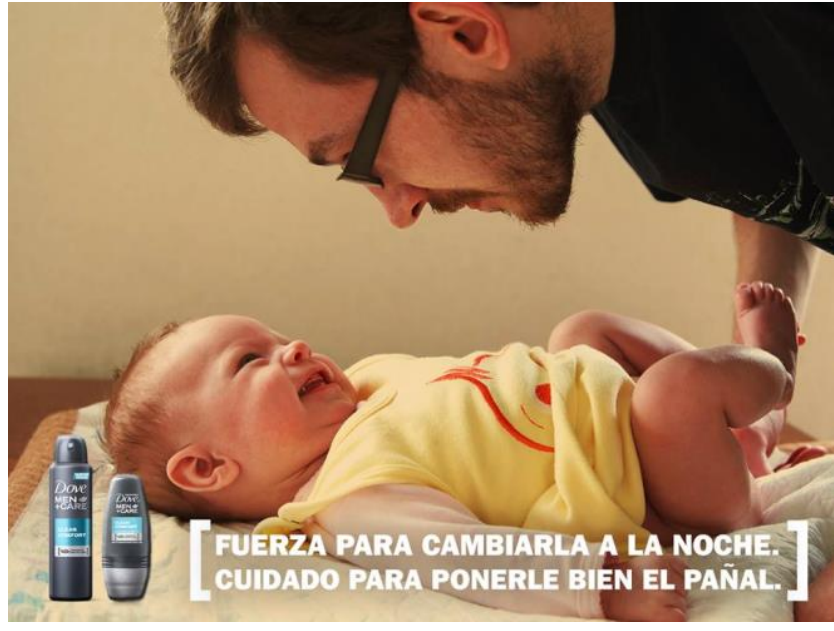

Figura 18: Dove Men+Care (@dovemencarear) (7 de junio de 2015). Epígrafe: “Antitranspirantes Dove Men+Care, el equilibrio entre potencia y cuidado" (Actualización Facebook). Recuperado de https://bit.ly/2q8ralj

Si bien Dove Men+Care marca una diferencia respecto a los vínculos paterno-filiales, quedan aún resabios de la supuesta complementariedad entre los sexos a la hora de distribuir las tareas del hogar. En la publicidad que afirma "Los hombres que cuidan también saben agasajar a sus familias con un gran desayuno un domingo a la mañana" (Figura 18), lo que se está transmitiendo, en realidad, es que el varón cocina como algo excepcional, una ocasión especial (domingo), no una práctica cotidiana, por lo que se agregan los términos "agasajar" y "gran" (preparará algo elaborado y abundante). Mientras tanto, la imagen muestra a un varón joven en actitud perpleja y confundida (por la expresión de su rostro y su mano en la cabeza), revisando un libro de cocina. A través de una paradoja (se dice una cosa con palabras y se la niega con la imagen) se ayuda a perpetuar la noción de que los saberes sobre cocina son propios de las mujeres. 


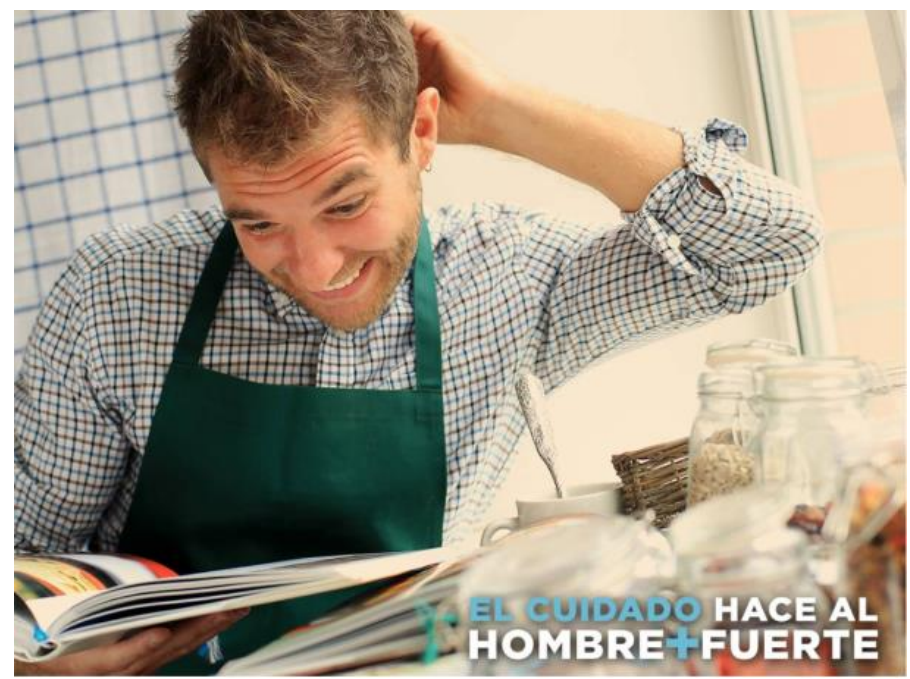

Figura 19: Dove Men+Care (@dovemencarear) (15 de enero de 2016). Epígrafe: Los hombres que cuidan también saben agasajar a sus familias con un gran desayuno un domingo a la mañana. (Actualización Facebook). Recuperado de https://bit.ly/2JeBg2K

La campaña publicitaria de Rexona recupera situaciones de la vida cotidiana, con un tinte humorístico y estilizado, en las que el desodorante vendría a evitar el oler mal: quedarse dormido/a en un día de trabajo, tener que correr para alcanzar el colectivo, intentar llegar al supermercado antes de que cierre, entre otras (Figura 20). También se incluyen desafíos o circunstancias significativas, como tener que dar una charla ante una multitud $o$ irse a vivir solo/a. En muchas de sus publicidades se incluyen las presentaciones del producto para mujeres y para varones. 


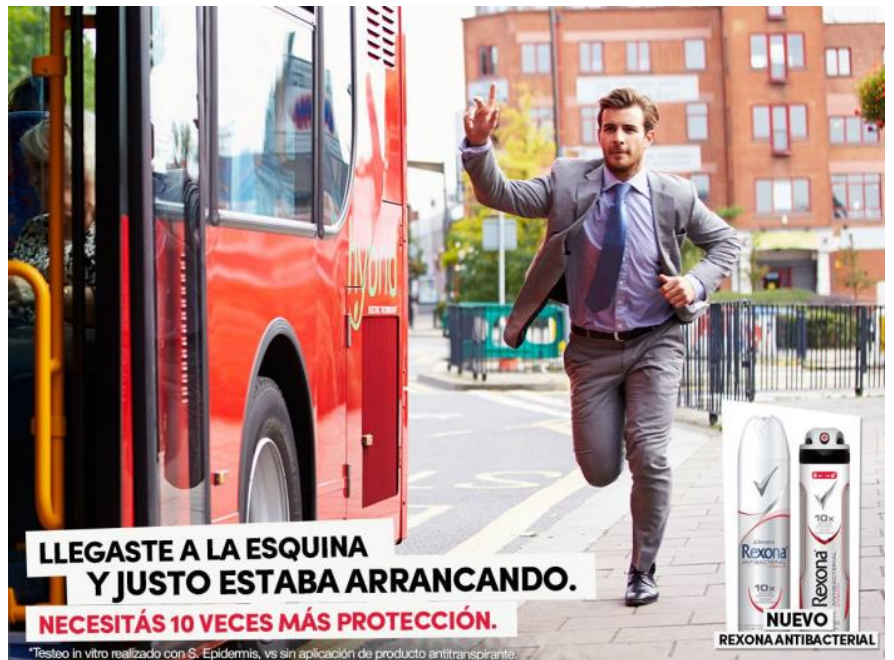

Figura 20: Rexona (RexonaArgentina) (13 de enero de 2015). Epígrafe: "Las situaciones que te hacen transpirar van a seguir. Vos también. Nuevo Rexona Antibacterial, 10 veces más protección contra las bacterias* que causan el mal olor". (Actualización Facebook). Recuperado de https://bit.ly/2lqo5ul

Los y las protagonistas de las publicidades de Rexona presentan cierta diversidad en cuanto a estilos de vida, profesiones y actividades artísticas. Sin embargo, se presentan ciertas publicidades que muestran situaciones incómodas vividas por no adecuarse al estándar de masculinidad esperado socialmente. Ejemplo de esto es el de un varón que, al conocer a su suegro, le da un beso en la mejilla, pero el suegro le había extendido la mano (Figura 21). En Argentina, saludarse con un beso es aceptado entre mujeres, cuando se saludan un varón con una mujer y cuando se saludan varones con lazos de familia o amistad; mientras que darse la mano es un saludo más distante, común entre varones. Incluso cuando hay confianza, es frecuente entre varones usar un saludo con las manos, más informal, que a veces incluye una palmada en la espalda con la otra mano, o un encuentro de hombros contrarios (Figura 22). 


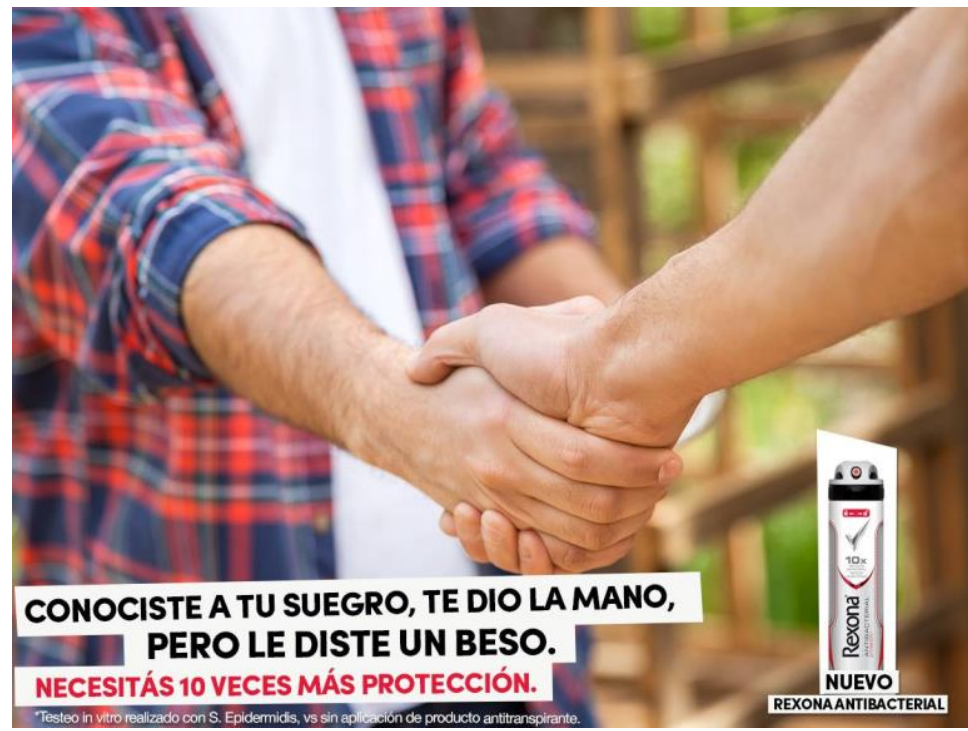

Figura 21: Rexona (RexonaArgentina) (14 de abril de 2015). Epígrafe: "Las situaciones que te hacen transpirar van a seguir. Vos también. Nuevo Rexona Antibacterial, 10 veces más protección contra las bacterias* que causan el mal olor". (Actualización Facebook). Recuperado de https://bit.ly/2GyKsNU

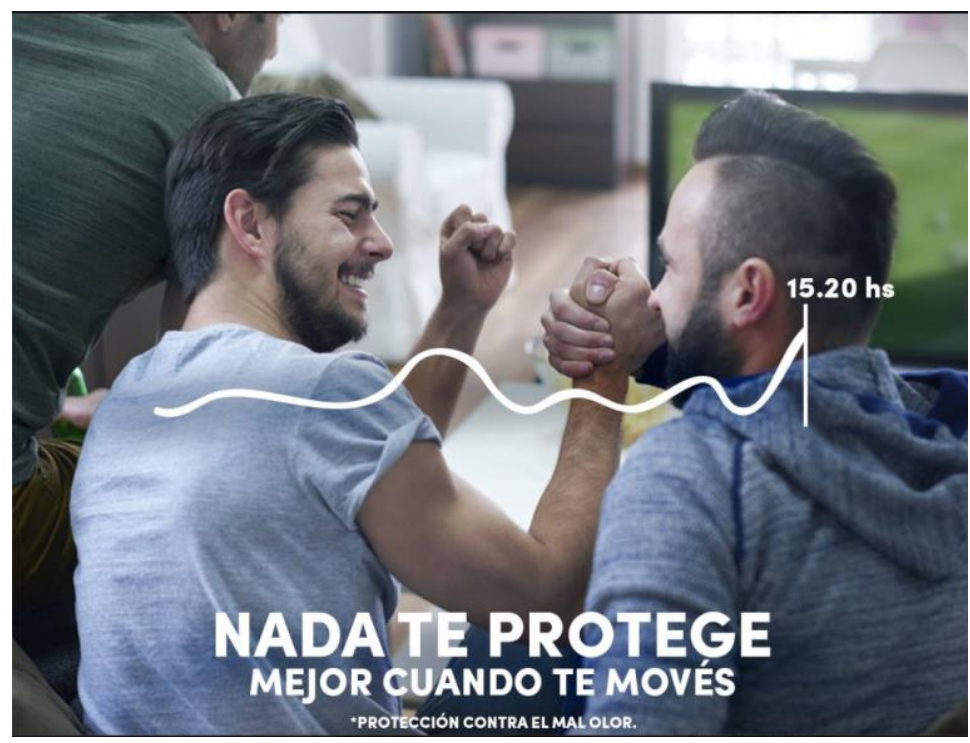

Figura 22: Rexona (RexonaArgentina) (9 de noviembre de 2015). Epígrafe: "Rexona con MotionSense te brinda protección extra* con cada movimiento. Incluso cuando llega el delivery y el partido ya empezó". (Actualización Facebook). Recuperado de https://bit.ly/2GzH3IK

Rexona usa imágenes de varones jóvenes (entre 20 y 30 años aproximadamente), a veces vestidos con traje, otras con ropa casual de moda, con cortes de cabello acordes a las últimas 
tendencias, delgados (aunque no revelan tanta preocupación por los músculos como los varones que muestran Gillette y Nivea). El nivel socioeconómico parece ser heterogéneo, pero superior a la media: aunque se muestran varones que van a trabajar en bicicleta o en colectivo, otros aspectos como su ropa, reloj, calzado, corte de cabello, indican un poder adquisitivo confortable.

\section{Reflexiones finales}

En la actualidad -más que nunca-, las publicidades son importantes transmisoras de lo que una cultura espera de las personas pero, también, de lo que rechaza. Gracias al acceso inmediato a la cotidianidad de las personas brindado por internet, las publicidades pueden influir en la configuración de las identidades: son tecnologías sociales generizadas y generizantes, que condensan y ponen en circulación los modelos de ser varón y de ser mujer valorados socialmente (Belmonte, 2014; Belmonte y Guillamón, 2008; De Lauretis, 1996).

Por un trabajo de producción semiótica, cuyo resultado son las publicidades, distintas marcas (que no significan nada en sí mismas), se vuelven perceptibles en la actividad de consumo. Las publicidades funcionan como artificios, instrumentos de persuasión y seducción, mezclando hábilmente mimetismo y aspiración: los varones se identifican con los modelos ideales, porque estos fueron elegidos por su cercanía, pero aspiran a conseguir lo que les falta y los diferencia de esos modelos, que estaría dado, en teoría, por los productos de una marca particular.

Las publicidades personalizadas, contextualizadas e interactivas proponen ideales de masculinidad, aunque sean inalcanzables, por ser construcciones publicitarias (Caro, 2017). Las mismas operan como guías para los jóvenes que buscan parámetros de referencia. Los varones se ven interpelados por esas propuestas y toman posición respecto a ellas para su constitución identitaria, en la construcción de su propia masculinidad: pueden intentar ajustarse a esas prescripciones, o usarlas como un modelo al que resistir, distanciándose de él (Connell y Messerschmidt, 2005).

A primera vista, las publicidades estudiadas parecen ofrecer múltiples opciones identitarias. Sin embargo, la mayoría de estas permanece ligada al consumo de fantasías patriarcales. Se sigue presionando y sugestionando a los varones para que adopten una heterosexualidad activa, ejerzan el poder y demuestren independencia. La masculinidad aparece sistemáticamente asociada a términos como "energía", "potencia", "fuerza" y "protección" (Lomas, 2003). Los modelos de rey/campeón, ganador/exitoso y deportista resistente son reforzados 
sistemáticamente. Las campañas de Dove, Nivea, Gillette y Rexona ubican al fútbol y a los futbolistas consagrados como emblemas de la masculinidad. El ámbito futbolístico es recuperado y presentado como el espacio donde los varones se prueban como hombres (su potencia, vigor, habilidad) y como amigos (valorando el compañerismo).

En las campañas de Gillette y Nivea se enaltece la agresividad, la competitividad, la acción, el riesgo y la iniciativa. La forma en que las publicidades de Gillette incentivan a "darlo todo", a "ponerse a prueba" constantemente, y las de Nivea que valoran la resistencia, la fuerza y el "aguante", pueden implicar descuidar la propia salud en pos de alcanzar un ideal de musculatura o de desempeño deportivo. Estos esfuerzos se apoyan en el temor a perder el reconocimiento del grupo de pares varones, a ser considerado débil (lo que se construye como propio de la feminidad). La virilidad es, para Bourdieu (2000) y Segato (2006) un concepto relacional, que se forja delante de y para los otros varones y en oposición a la feminidad. Por esto, Bourdieu considera a la valentía como un tipo de cobardía.

Si bien en las publicidades de Dove se habla de mostrar la "potencia" o "fuerza", al haber incorporado el factor "cuidado" (como equilibrante del primero), puede contrarrestarse el extremo que se alcanza en las de Gillette (aunque el cuidado está planteado hacia la familia y amigos, no hacia sí mismo).

Las publicidades de Gillete, que incitan a los varones a afeitarse el vello de la espalda, torso, axilas, ingle, rostro, indican que, efectivamente $-y$ como se hace con las mujeres-, a los varones se les está demandando un ideal de belleza que está por fuera de lo real (Cuadrado Zurinaga, 2008). Como los metrosexuales se asocian fácilmente a la homosexualidad (Rey, 2006), las publicidades de Gillette buscan ligar la depilación con un varón que "caza" los vellos de su "territorio" corporal.

Lomas (2003) y Bonino Méndez (1998) ubicaban al modelo de varón hegemónico en un egocentrismo que lo llevaba a anteponer su éxito profesional y su ocio al cuidado del hogar y de su familia. Si bien ninguna de las campañas aquí estudiadas ubica a los varones implicados en labores de limpieza o cuidado del hogar, la paternidad sí ha dejado de ser mostrada como la mera previsión de un salario y por la presencia sólo en los eventos significativos de la vida de los hijos e hijas. Las publicidades de Dove presentan a padres involucrados en la crianza, recuperando el sentido de las experiencias compartidas, del cuidado cariñoso y de la transmisión de saberes y prácticas en la vida doméstica. Las publicidades de Dove celebran y promueven aspectos de la masculinidad que reflejan un cambio cultural, lo que permite ampliar el panorama de los afectos que los varones pueden mostrar públicamente (la ternura hacia sus hijos e hijas) sin que se ponga en duda su hombría. 
Los varones publicitarios de la marca AXE son presentados como personas con absoluto control sobre sí mismos o de la situación en que se encuentran. Nada les hace perder su estilo. El interés principal de estos varones es el placer y la diversión, vinculada a fiestas nocturnas. Los varones ofrecidos como modelos son jóvenes, delgados, se muestran seductores, espontáneos, confiados, y se valora su actitud, como algo que les permite usar alguna prenda o accesorio fuera de lo común.

Las publicidades de Rexona sobresalen por presentar sucesos importantes o situaciones incómodas de la vida cotidiana, que pueden ocurrir tanto a varones como a mujeres. No se observa una marcada jerarquía entre varones, salvo situaciones entre empleado/jefe o yerno/suegro. Además, es destacable la diversidad de modos de vida que recupera, siempre y cuando estos reflejen una actitud activa, y esa actitud no es privativa de los varones. En cuanto al perfil de varón que construye la marca, el ideal es el de un varón joven, heterosexual, trabajador, para el cual el deporte aparece vinculado a una vida saludable (ir a trabajar o salir a pasear en bicicleta o en skateboard) o a los lazos con otros pares de género (jugar al fútbol con amigos). Por esto, si bien sus publicidades muestran varones delgados, la preocupación por la musculatura no es evidente en las imágenes, ni en los mensajes que las acompañan.

La masculinidad hegemónica varía cultural y temporalmente, lo que implica que la jerarquía entre los distintos modos de ser varón también cambia (Connell y Messerschmidt, 2005). Las publicidades de las distintas marcas analizadas enaltecen la solidaridad y la camaradería entre varones, con el freno que impone el miedo a la homosexualidad. En las publicidades de Nivea el precepto es el de ser un ganador, un campeón, interesado en cómo se luce, cuidando la piel y la musculatura, pero cuidando no afeminarse. Las actitudes, prácticas, características, gestualidades o corporalidades que puedan asociarse a lo femenino $o$ a la homosexualidad son ridiculizadas y censuradas (Belmonte y Guillamón, 2008). Esto se transmite previniendo a los varones de hacer uso de ciertos colores (especialmente el rosa), y dando ideas para que, al hacer regalos románticos a sus parejas (que siempre se presumen mujeres), estos tengan una cuota de masculinidad (por ejemplo, buscando que un oso de peluche lleve puesta la camiseta del equipo de fútbol preferido). Así, se neutralizaría lo femenino del regalo romántico y se salvaría la reputación del varón.

Las publicidades de las distintas marcas estudiadas muestran, como modelos ideales, a varones blancos, jóvenes, heterosexuales, urbanos, de clase media o alta, profesionales y deportistas, ubicándolos por sobre otras formas de ser varones. Es importante reconocer que la hegemonía no se manifiesta sólo a través de la censura explícita de otras masculinidades sino, también, mediante su invisibilización (Connell y Messerschmidt, 2005). Las publicidades no 
sólo dejan a gran parte de la población sin representación, sino que deslegitiman sus modos de ser y estar en el mundo y, por eso, implican violencia simbólica. Estudiar el modo en el que los varones se vinculan en su cotidianidad con ese modelo dominante puede ayudar a comprender las implicancias que el género tiene sobre la violencia, la salud y la educación, dado que es una ventana a ciertas dinámicas sociales (Connell y Messerschmidt, 2005).

Ante este panorama, se acuerda con Belmonte (2014) acerca de la necesidad educativa de hacer una pedagogía de la mirada, que permita una relación con la imagen en los planos político, estético y ético, brindando herramientas a la población para la interpretación y el análisis crítico de los discursos manejados en los medios de comunicación, dado que al ser éstos composiciones retóricas complejas, su sólo consumo no es garantía de una verdadera comprensión de los mismos. La reflexión sobre el carácter persuasivo de las imágenes y los mensajes a los que la población está continuamente expuesta, puede brindar herramientas que favorezcan la identificación y el cuestionamiento de los mecanismos narrativos, semióticos e interpelativos que se ponen en juego (Belmonte, 2014; Belmonte y Guillamón, 2008) en la reproducción de los estereotipos de género.

\section{Notas}

(1) Foucault, M. (1980). The History of Sexuality. Vol. I: An Introduction. (Trad. Robert Hurley). Nueva York: Vintage Books.

(2) El término se acuñó en 1994, pero cobró auge en 2002.

(3) AXE, Rexona y Dove son marcas de Unilever.

(4) Rexona [RexonaArgentina] (30 de noviembre de 2015). Rexona con MotionSense te brinda protección extra* con cada movimiento. Incluso cuando tenés que llegar al banco antes de que cierre. (Actualización Facebook). Recuperado de https://bit.ly/2H7HYqB

\section{Bibliografía}

Belmonte, J. (2014). Del arte cinematográfico a la imagen postelevisiva: co-educación audiovisual ante las representaciones de la feminidad. Dossiers Feministes, 19, 149167.

Belmonte, J. y Guillamón, S. (2008). Co-educar la mirada contra los estereotipos de género en TV. Comunicar, 31, 115-120. Recuperado de http://dx.doi.org/10.3916/c31-2008-01-014 
Berger, J. (2002). Modos de ver (7ma Edición). Barcelona: Ed. Gustavo Gilli.

Bonino Méndez, L. (1998). Micromachismos: La violencia invisible en la pareja. Ponencia presentada en Jornadas sobre Hombres e igualdad, Universidad de Zaragoza, España.

Bourdieu, P. (2000). La dominación masculina. Barcelona: Edit. Anagrama.

Butler, J. (2002). Cuerpos que importan: sobre los límites materiales y discursivos del "sexo". Buenos Aires: Edit. Paidós.

Caro, A. (2017). Comprender la publicidad (2ª edición). San Miguel de Tucumán: Librería Humanitas, Universidad Nacional de Tucumán, Facultad de Filosofía y Letras.

Connell, R. (1997). La organización social de la masculinidad. Recuperado de http://higualitaris.grunyi.net/wordpress/wp-content/uploads/organizacion-socialmasculinidad-connell.pdf

Connell, R. W. y Messerschmidt, J. W. (2005). Hegemonic Masculinity: Rethinking the Concept. Gender and Society, 19(6), pp. 829-859. Recuperado de http://journals.sagepub.com/doi/abs/10.1177/0891243205278639?journalCode=gasa

Cuadrado Zurinaga, M. (2008). El género femenino a través de la publicidad. Recuperado de http://www.educarenigualdad.org/media/pdf/uploaded/material/401_2016oct20-el-ganero-femenino-a-trava-s-de-la-publicidad-pdf.pdf

De Lauretis, T. (1996). La tecnología del género. En Technologies of Gender. Essays on Theory, Film and Fiction, London Macmillan Press, 1989, pp. 1-30. Recuperado de http://blogs.fad.unam.mx/asignatura/adriana_raggi/wp-

content/uploads/2013/12/teconologias-del-genero-teresa-de-lauretis.pdf

Hernández García, Y. (2006). Acerca del género como categoría analítica. Nómadas Revista Crítica de Ciencias Sociales y Jurídicas, 13, Universidad Complutense, Madrid.

Lomas, C. (comp.) (2003) ¿Todos los hombres son iguales? Identidades masculinas y cambios sociales. Barcelona-Buenos Aires: Edit. Paidós.

Margulis, M. y otros (2003). Juventud, Cultura, Sexualidad. La dimensión cultural en la afectividad y la sexualidad de los jóvenes de Buenos Aires. Buenos Aires: Edit. Biblos.

Porras, L. y Molina, S. (2011). Manual de Género para Periodistas. Recomendaciones básicas para el ejercicio del periodismo con enfoque de género. Área Práctica de Género del Programa de las Naciones Unidas para el Desarrollo en América Latina y El Caribe (RSCLAC, PNUD). Recuperado de http://www.americalatinagenera.org/es/documentos/ Folleto_ManualdeGenero.pdf

Rey, J. (2006). Los «metrosexuales» y «übersexuales» como artefactos publicitarios. Nuevos modelos para nuevos consumidores. Comunicar. Revista Científica de Comunicación y 
Educación, 27, pp. 19-27. Recuperado de http://www.redalyc.org/articulo. oa?id=15802704

Segato, R. (2006). La escritura en el cuerpo de las mujeres asesinadas en Ciudad Juárez: Territorio, soberanía y crímenes de segundo estado. México: Universidad del Claustro de Sor Juana. Colección Voces.

Segato, R. (2010). Las estructuras elementales de la violencia: Ensayos sobre género entre la antropología, el psicoanálisis y los derechos humanos. Buenos Aires: Ed. Prometeo Libros.

Urbano, C. y Yuni, J. (2011). Esos cuerpos que envejecen. Córdoba: Edit. Brujas.

Weeks, J. (2012). Lenguajes de la sexualidad. Buenos Aires: Edit. Nueva visión. 